\title{
Ownership of latrine in the household in Indonesia: a review
}

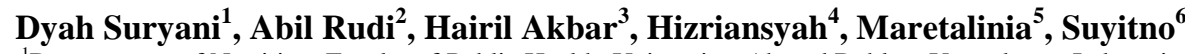 \\ ${ }^{1}$ Departement of Nutrition, Faculty of Public Health, Universitas Ahmad Dahlan, Yogyakarta, Indonesia \\ ${ }^{2}$ Health Information Record Programe, Kapuas Raya College of Health Science, Sintang, Indonesia \\ ${ }^{3}$ Public Health Program, Graha Medika Institute of Health and Technology, Kotamobagu, Indonesia \\ ${ }^{4}$ Department of Public Health, Faculty of Medicine, Public Health and Nursing, Gadjah Mada University, Yogyakarta, Indonesia \\ ${ }^{5}$ Institute Population and Social Research, Mahidol University, Salaya, Thailand \\ ${ }^{6}$ Master of Primary Health Care Management, ASEAN Institute for Health Development, Mahidol University, Salaya, Thailand
}

\begin{tabular}{l} 
Article Info \\
\hline Article history: \\
Received Apr 5, 2021 \\
Revised Nov 9, 2021 \\
Accepted Nov 22, 2021 \\
\hline Keywords: \\
Household latrine \\
Open defecation free (ODF) \\
Ownership of latrine \\
Sanitation
\end{tabular}

Sanitation

\begin{abstract}
Ownership of a household latrine has been proven to be associated with various diseases, including diarrhea. This study aimed to understand the factors related to ownership of latrine in the household, Indonesia. This study used a literature review design by collecting 15 articles screened according to the inclusion and exclusion criteria using the preferred reporting items for systematic review and meta-analysis (PRISMA) Model. It was found that attitude was significantly related to ownership of healthy latrines in the household. The level of knowledge, family income, the level of education, and the role of health practitioner were also the most significant variables in Indonesia during 2010 to 2020. The government needs to make the sanitation campaign and creative intervention to reach $100 \%$ open defecation free in Indonesia.
\end{abstract}

This is an open access article under the CC BY-SA license.

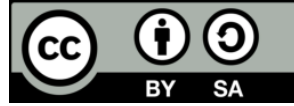

\section{Corresponding Author:}

Dyah Suryani

Faculty of Public Health, Universitas Ahmad Dahlan

Jl. Prof. DR. Soepomo SH., Warungboto, Umbulharjo, Yogyakarta, Special Region of Yogyakarta 55164, Indonesia

Email: dyah.suryani@ikm.uad.ac.id

\section{INTRODUCTION}

At the point six, one of the aims of the sustainable development goals (SDGs) is the availability of good sanitation, for better public health and welfare [1] Open defecation practice remains 18\% in the rural population and $1 \%$ in the urban population worldwide. Nine of ten open defecations occur in rural areas, and the poor are more likely to do so [2].

During 2000 to 2017, Indonesia only could increase of 100 million people who had access to basic sanitation services [3]. Then, there was still $18 \%$ of the population in Indonesia who did not defecate properly in 2018 [4] and in 2019, 25 million Indonesians did not have access to healthy latrines, so they defecated in fields, shrubs, forests, ditches, roads, rivers or other open spaces [5].

In 2017 , households that had access to proper and sustainable sanitation were $53.51 \%$, it increased to $55.47 \%$ in 2018, and in 2019 increased to $66.57 \%$ [6]. However, disparities in health development related to healthy family indicators still occur in Indonesia [7] and in Cambodia, too [8]. One indicator of a healthy family is that the family has access to use a healthy latrine [9]. As in the results of a study in North of South Konawe, Southeast Sulawesi Province, it was found that $81 \%$ of respondents did not defecate in the toilet [10].

The increasing of household head education level has a positive effect on the ownership of latrines at the community level [11]. The education level of the household head is not absolutely influencing his 
health knowledge [12]. It because, the ownership of the toilet is influenced by many aspects such as behavior, culture, social, geographical, and economic in various members of the community [13]-[15]. Moreover, the use of healthy latrines by households is influenced by support from community leaders and the role of health workers [16].

The attitude of the head of the household is a psychological predictor of latrine ownership and becomes one of the determinants in the consistency of using toilet in the household [17]. The parameters of the attitude and perception of household heads significantly affect consistent use of latrines [18], [19]. In addition, the ownership of the toilet also tends to be influenced by income [20] become the main aspect that influences latrine utilization [21] and the most important thing is family income as a determinant of household latrine ownership [22].

Ownership of a latrine is one of the factors associated to the incidence of diarrhea [23]. The most dominant cause of diarrhea in children under five is the use of family latrines [24]. The condition of household latrines has a strong relationship to the use of latrines and the incidence of diarrhea [25], [26]. Therefore, this study will collect all scientific articles from 2010 to 2020 in Indonesia that will be reviewed and made conclusions. The aim of this study is to find out the factors that influence the elimination of family latrines in Indonesia and the results of this study can be used to achieve open defecation free (ODF) in Indonesia.

\section{METHOD}

This literature review design used some articles started from first of October 2020. This study uses the e-data bases such as; Google Scholar, Neliti.com, and ProQuest. Keywords and term used in this study consist of Indonesian and English. In English are; latrine, family toilet, household toilet, ownership of family toilet, ownership of household toilet, and ownership of toilet. In Bahasa Indonesia are: jamban, jamban keluarga, jamban rumah tangga, kepemilikan jamban keluarga, kepemilikan jamban rumah tangga, dan kepemilikan jamban.

This literature review research had the following inclusion criteria: scientific journals published in the last 10 years starting from 2010 to 2020. The articles were only those conducted in Indonesia. The subjects observed in this study were ownership of latrine in the household. Regarding ownership of latrine in the household, scientific journals are taken not in abstract only published but must be in full text (full text was available). The PRISMA model was also used for include and exclude the criteria of the articles (http://www.prisma-statement.org/). After dwelling articles were evaluated for any strong findings on ownership of the latrine in the household, totally 15 articles picked for the final inclusion as shown in Figure 1.

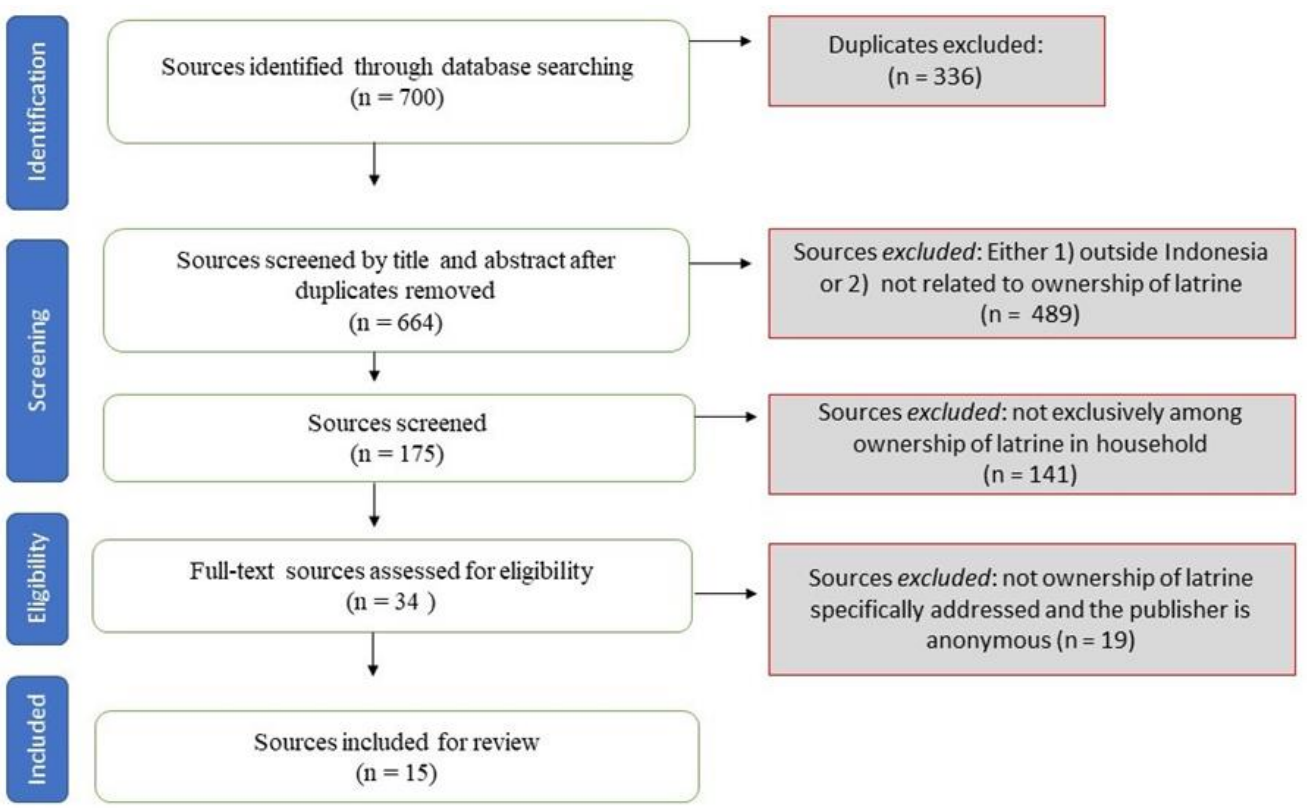

Figure 1. Modified from PRISMA flow diagram for screening articles of ownership of latrine in the household in Indonesia 
This study found 15 studies about ownership of latrine in Indonesia (Table 1) (see Appendix). Vabriables that most have significant correlation with ownership of latrine in Indonesia were attitude, knowledge, family income, level of education, and role of health practitioner. For attitude variables that significant correlated with the ownership of latrine could be seem in the study numbers $3,4,5,6,7,8,9,10$, 11, and 13. Knowledge factors could be founded in number 3, 4, 6, 7, 8, 9, 12, 13, and 14. Family income/economic status are in the number 3,6,9,10,11,12,13, and 15. Level of education variables could be finded in the study number $3,4,5,6,7$, and 13 . Role of health worker showed in the number $1,9,12,13$, and 14.

\section{RESULTS AND DISCUSSION}

In this study, we found all of the articles published from 2010 to 2020 in Indonesia about ownership of latrines in the household. The majority of findings showed the ownership of latrines in the household was more than 50\%. It has been describing what happened in the community. From Indonesia national data 2021 were showed merely 81.3 households have access to the latrine in Indonesia [42]. In the fact, ownership of latrine in the household has significantly predictor to some popular disease like diarrhea, cholera, pneumonia, typhoid also social network [20]. The government must be serious to overcome this condition, like making the priority program $100 \%$ open defecation free (ODF).

From all independent variables, it was found the attitude as the top predictor of ownership of latrine in the household. The previous study from Ethiopia showed the same result [17]. Attitudes are often associated with a person's behavior or actions towards something because people who have a low standard of living will practice defecating in the open air [43]. This is different from the results of ethnographic studies in Ecuador which reported the absence of health facilities and individual factors from rural communities that cause someone to defecate in the open [44]. Therefore, ownership of a latrine in the household will exist if the head of the family or household members has a good attitude towards the importance of having a latrine in their own house (private).

The level of knowledge in this study as the second predictor of ownership of latrine. This is not too different with the results of previous research conducted in India [45], [46]. The level of knowledge is often associated with a person's behavior. People's behavior is different in facing change. Such as socio-cultural factors as the cause of the inhibition of latrine construction in India [47]. This shows the need for seriousness in detail from various aspects by the government in making a project to build latrines in the community.

The third variable that related to ownership of latrine in this study was family income. The results of this study are in line with previous research in India conducted by Shakya which shows that one of the main factors of family latrine ownership in household households in India is household income [20]. Then it is supported by the results of research in North West Ethiopia which has the result that households with low incomes are three times more likely to have no latrine in their household [22]. Therefore, the economic level of the household or family income is one of the factors related to ownership of a latrine in the household. For policy makers, it is necessary to implement innovative programs such as joint venture of money for latrine each household that does not have a latrine.

Base on the findings of this study, the role of health practitioners as fourth variable that significant to ownership of latrine in this study. This result is in line with previous research conducted by Ross which stated that the role of health workers has a very significant effect on household ownership of latrines [48]. Therefore, the role of health workers is very important in changing people's behavior. So, it is necessary to improve health services at the primary level, especially in places with low family latrine ownership coverage. The training about healthy latrines and the indicators of healthy household could be useful to increase the health personal's capacity and knowledge.

The educational level also significantly related to ownership of latrine in this study. It was not very different with the result from previous review study in Indonesia which revealed that the level of education, level of knowledge, and attitude are the variables that are most associated to ownership of latrine in Indonesia [49]. Then, another study in Ethiopia showed the demographic factors were significantly associated with availability of the toilet in the households [50]. Based on a study in Thailand, it shows that to overcome the latrine problem in the country it is necessary to make several important points such as a strong policy for latrine construction, integration of latrine development into health development, the right approach and strategy, adequate health facilities, and the will of the community [51]. The importance of campaigns and priority programs on sanitation carried out by the government.

\section{CONCLUSION}

In sum, the attitude variable is the main factor related to household ownership of latrines. Then, the respondent's level of knowledge is the second causative factor. Economic level/family income is the third 
contributing factor. The role of health workers has the fourth influence and the last is the level of education of the respondents who at least had a significant relationship to latrine ownership in Indonesia from 2010 to 2020. Researchers in environmental health need to enhance research on household latrine ownership in Indonesia. Then, the government need to provide the new creative programs to reach the target every household in the regions in Indonesia has $100 \%$ of the latrine.

\section{REFERENCES}

[1] United Nation, "Sustainable development goals," United Nations Department of Public Information, 2015. Available: https://sustainabledevelopment.un.org/sdgs (accessed: May 29, 2020).

[2] UNICEF and WHO, "Progress on household drinking water, sanitation and hygiene 2000-2017: Special focus on inequalities." 2019. https://www.unicef.org/media/55276/file/Progress (accessed: May 29, 2020).

[3] UNICEF, "Progress on sanitation and drinking water: 2015 update and MDG assessment." https://www.unicef.org/reports/progress-sanitation-and-drinking-water (accessed May 29, 2020).

[4] Ministry of Health Republic of Indonesia, "Main results of basic health research (RISKESDAS) (In Indonesia: Hasil utama riset kesehata dasar (RISKESDAS))," Kementerian Kesehatan Republik Indonesia, $2018 . \quad$ [Online]. Available: https://www.litbang.kemkes.go.id/hasil-utama-riskesdas-2018/ (accessed May 29, 2020).

[5] UNICEF, "Water, sanitation and hygiene (In Indonesia: Air, sanitasi dan kebersihan (WASH))," UNICEF Indonesia, 2020. https://www.unicef.org/indonesia/id/air-sanitasi-dan-kebersihan-wash (accessed May 29, 2020).

[6] BPS, "Percentage of households with access to adequate and sustainable sanitation services, by province (Percent) 2017-2019 (In Indonesia: Presentasi rumah tangga yang memiliki akses terhadap layanan sanitasi layak dan berkelanjutan, menurut provinsi (Persen) 2017-2019," 2020. https:/www.bps.go.id/indicator/23/1558/1/persentase-rumah-tangga-yang-memiliki-akses-terhadaplayanan-sanitasi-layak-dan-berkelanjutan-40-bawah-menurut-provinsi.html (accessed May 29, 2020).

[7] H. Maryani, L. Kristiana, A. Paramita, and N. Izza, "Health development disparities in Indonesia based on healthy family indicators using cluster analysis (In Indonesia: Disparitas pembangunan kesehatan di Indonesia berdasarkan indikator keluarga sehat menggunakan analisis cluster)," Buletin Penelitian Sistem Kesehatan, vol. 23, no. 1, pp. 18-27, May 2020, doi: $10.22435 /$ hsr.v23i1.2622.

[8] S. Sreymogn, C. Var, and S. Chan, "Determinants of toilet ownership among households in Cambodia: data analysis of violence against women survey (VAWS) 2015," Cambodia J. Public Heal. Sch. Public Heal. NIPH, vol. 2, no. 4A, 2021,

[9] Ministry of Health Republic of Indonesia, "Healthy Indonesia program with a Family Approach (PIS-PK) (In Indonesia: Program Indonesia sehat dengan pendekatan keluarga (PIS-PK))." 2017. http://pispk.kemkes.go.id/id/program-pispk/pelaksanaanpendekatan-keluarga-sehat/ (accessed May 29, 2020).

[10] H. Lestari, H. Bahar, P. Asfian, and L. O. Ali Imran Ahmad, "Environmental risk factors in Coastal Area of Wawatu Village, Moramo Sub District, North of South Konawe, Southeast Sulawesi," Public Health of Indonesia, vol. 3, no. 3, pp. 107-111, Sep. 2017, doi: 10.36685/phi.v3i3.133.

[11] G. Gebremedhin et al., "Factors associated with latrine utilization among model and non-model families in Laelai Maichew Woreda, Aksum, Tigray, Ethiopia: comparative community based study,” BMC Research Notes, vol. 11, no. 1, p. 586, Dec. 2018, doi: 10.1186/s13104-018-3683-0.

[12] K. Minamoto, C. G. N. Mascie-Taylor, E. Karim, K. Moji, and M. Rahman, "Short- and long-term impact of health education in improving water supply, sanitation and knowledge about intestinal helminths in rural Bangladesh," Public Health, vol. 126, no. 5, pp. 437-440, May 2012, doi: 10.1016/j.puhe.2012.02.003.

[13] H. Gebremedhin, T. Abay, T. Gebregzabher, D. Yemane, G. Gebreegziabiher, and S. Belay, "Latrine utilization and associated factors in south east zone of Tigray region, north Ethiopia," Eur. J. Biomed., vol. 3, no. 6, pp. 120-126, Dec. 2018, doi: 10.1186/s13104-018-3683-0.

[14] G. Asfaw, E. Molla, and P. K. Vata, "Assessing privy (Latrine's) utilization and associated factors among households in Dilla Town, Ethiopia," Int J Heal. Sci Res, vol. 5, no. 6, pp. 537-544, 2015.

[15] Y. T. Yimam, K. A. Gelaye, and D. H. Chercos, "Latrine utilization and associated factors among people living in rural areas of Denbia district, Northwest Ethiopia, 2013, a cross-sectional study," Pan African Medical Journal, vol. 18, 2014, doi: 10.11604/pamj.2014.18.334.4206.

[16] D. Sayati, "Factors that affect the use of healthy latrines in the Work Area of 23 Ilir Palembang Health Center in 2018 (In Indonesia: Faktor-faktor yang mempengaruhi pemanfaatan jamban sehat di Wilayah Kerja Puskesmas 23 Ilir Palembang Tahun 2018)," J. 'Aisyiyah Med, vol. 2, no. Agustus, pp. 57-68, 2018.

[17] F. Alemu, A. Kumie, G. Medhin, and J. Gasana, "The role of psychological factors in predicting latrine ownership and consistent latrine use in rural Ethiopia: a cross-sectional study," BMC Public Health , vol. 18, no. 1, Feb. 2018, doi: 10.1186/s12889-0185143-0.

[18] R. A. Tessema, "Assessment of the implementation of community-led total sanitation, hygiene, and associated factors in Diretiyara district, Eastern Ethiopia," PLOS ONE, vol. 12, no. 4, p. e0175233, Apr. 2017, doi: 10.1371/journal.pone.0175233.

[19] Vera Yulyani, Dina Dwi N, and Dina Kurnia, "Latrine use and associated factors among rural community in Indonesia," Malaysian Journal of Public Health Medicine, vol. 19, no. 1, pp. 143-151, Jan. 2019, doi: 10.37268/mjphm/vol.19/no.1/art.46.

[20] H. B. Shakya, N. A. Christakis, and J. H. Fowler, "Social network predictors of latrine ownership," Social Science \& Medicine, vol. 125, pp. 129-138, Jan. 2015, doi: 10.1016/j.socscimed.2014.03.009.

[21] N. Debesay, "Latrine utilization and associated factors in the rural communities of Gulomekada District, Tigray Region, North Ethiopia, 2013: a community based cross-sectional study," Journal of Community Medicine \& Health Education, vol. 05, no. 02, pp. 120-126, 2015, doi: 10.4172/2161-0711.1000338.

[22] Y. Tafere, M. Woldie, and H. Assefa, "Investigations of latrine coverage and associated factors among Debretabor town, Amhara Region North west Ethiopia,” International Journal of Public Health Science (IJPHS), vol. 5, no. 2, pp. 137-141, Jun. 2016, doi: 10.11591/.v5i2.4777.

[23] P. Patmawati, "Factors related to the incidence of diarrhea in Bonne-Bonne Village, Mapilli District, Polewali Regency (In Indonesia: Faktor-faktor yang berhubungan dengan kejadian diare Di Desa Bonne-Bonne Kecamatan Mapilli Kabupaten Polewali)," J-KESMAS J. Kesehat. Masy., vol. 3, no. 1, pp. 58-65, 2018.

[24] S. A. Taosu and R. Azizah, "The relationship between basic household sanitation and the behavior of housewives with the

Int J Public Health Sci, Vol. 11, No. 1, March 2022: 149-156 
incidence of diarrhea in children under five in Bena Village, East Nusa Tenggara (In Indonesia: Hubungan sanitasi dasar rumah dan perilaku ibu rumah tangga dengan kejadian diare pada balita di Desa Bena Nusa Tenggara Timur)," J. Kesehat. Lingkung, vol. 7, no. 1, pp. 1-6, 2013.

[25] A. Y. Irawan, "The relationship between environmental health aspects in household PHBS with the incidence of diarrheal disease in Karangreja sub-district in 2012 (In Indonesia: Hubungan antara aspek kesehatan lingkungan dalam phbs rumah tangga dengan kejadian penyakit di Karangreja 2012)," Unnes J. Public Heal, vol. 2, no. 4, 2013.

[26] R. A. Pebriani, S. Dharma, and E. Naria, "Factors related to the use of family latrines and the incidence of diarrhea in Tualang Sembilar Village, Bambel District, Southeast Aceh Regency in 2012 (In Indonesia: Faktor-faktor yang berhubungan dengan penggunaan jamban keluarga dan kejadian diare Di Desa Tualang Sembilar Kecamatan Bambel Kabupaten Aceh Tenggara Tahun 2012)," Lingkung. dan Keselam. Kerja, vol. 2, no. 3, p. 14412, 2013.

[27] A. arfah Pulungan, W. Hasan, and N. Nurmaini, "Factors associated with family latrine ownership in sipange julu village, sayur matinggi district, South Tapanuli Regency in 2013 (In Indonesia: Faktor-Faktor Yang Berhubungan Dengan Kepemilikan Jamban Keluarga Di Desa Sipange Julu Kecamatan Sayur Matinggi Kabupaten Tapanuli Selatan Tahun 2013)," Dep. Kesehat. Lingkung. Fak. Kesehat. Masy. Univ. Sumatera Utara, vol. 53, no. 9, pp. 89-99, 2013, doi: 10.1017/CBO9781107415324.004.

[28] S. Lestari, "Factors Relating to Factors Relating to Family Latrine Ownership in the Working Area of UPTD Puskesmas Kasokandel (In Indonesia: Faktor-Faktor Yang Berhubungan Dengan Faktor-Faktor Yang Berhubungan Dengan Kepemilikan Jamban Keluarga di Wilayah Kerja UPTD Puskesmas Kasokandel),” J. Kesehat., vol. 6, no. 2, pp. 13-14, 2015. In English: S. Lestari, "Factors Relating to Factors Relating to Family Latrine Ownership in the Working Area of UPTD Puskesmas Kasokandel," J. Kesehat., vol. 6, no. 2, pp. 13-14, 2015.

[29] O. Widyastutik, "Factors associated with ownership of healthy toilets in Malikian Village, West Kalimantan (In Indonesia: Faktor yang berhubungan dengan kepemilikan jamban sehat Di Desa Malikian, Kalimantan Barat)," Ikesma, vol. 13, no. 1, 2017, doi: 10.19184/ikesma.v13i1.5223.

[30] G. S. Putra and S. Selviana, "Factors associated with ownership of healthy toilets in Empakan Village, Kayan Hulu District (In Indonesia: Faktor-Faktor Yang Berhubungan Dengan Kepemilikan Jamban Sehat Di Desa Empakan Kecamatan Kayan Hulu)," J. Kesmas (Kesehatan Masyarakat) Khatulistiwa, vol. 4, no. 3, p. 238, 2017, doi: 10.29406/jkmk.v4i3.866.

[31] L. D. Kurniawati and R. Windraswara, "Factors Influencing the Behavior of the Head of the Family in the Use of Latrine in the Settlement of the Tambaklorok Fisherman's Village, Semarang, (In Indonesia: Faktor-Faktor yang Berpengaruh terhadap Perilaku Kepala Keluarga dalam Pemanfaatan Jamban di Pemukiman Kampung Nelayan Tambaklorok Semarang),” Public Heal. Perspect. J., vol. 2, no. 1, pp. 72-79, 2017.

[32] F. Novitry, "Determinants of healthy latrine ownership in Sukomulyo Martapura Village, Palembang (In Indonesia: Determinan Kepemilikan Jamban Sehat di Desa Sukomulyo Martapura Palembang)," AISYAH J. Ilmu Kesehat., vol. 2, no. 2, pp. 107-116, 2017.

[33] S. Yahya and N. Nursyamsi, "The relationship between education level, knowledge, and attitude with family toilet ownership in the Community in Ponci Hamlet, Polewali Village, Bulukumba Regency (In Indonesia: Hubungan Tingkat Pendidikan, Pengetahuan, dan Sikap Dengan Kepemilikan Jamban Keluarga Pada Masyarakat Di Dusun Ponci Desa Polewali Kabupaten Bulukumba)," Progr. Stud. S1 Keperawatan Stikes Panrita Husada Bulukumba, vol. 3, no. 1, pp. 13-23, 2018.

[34] M. Hirai, A. Kelsey, K. Mattson, A. A. Cronin, S. Mukerji, and J. P. Graham, "Determinants of toilet ownership among rural households in six eastern districts of Indonesia," J. Water Sanit. Hyg. Dev., vol. 8, no. 3, pp. 533-545, 2018, doi: 10.2166/washdev.2018.010.

[35] A. Arlin, S. Sudirman, and N. Nurafni, "Factors related to toilet ownership in Tanauge Village, Tomini District, Parigi Moutong Regency (In Indonesia: Faktor Yang Berhubungan dengan Kepemilikan Jamban di Desa Ta'aniuge Kecamatan Tomini Kabupaten Parigi Moutong)," Fak. Kesehat. Masyarakat, Univ. Muhammadiyah Palu, vol. 53, no. 9, pp. 89-99, 2019, doi: 10.1017/CBO9781107415324.004.

[36] D. L. Caesar and M. F. Riza, "Relationship between family behavior factors and latrine ownership in the village of Setro Kalangan, Kaliwungu sub-district, Kudus district (In Indonesia: Hubungan faktor perilaku keluarga dengan kepemilikan jamban Di Desa Setro Kalangan Kecamatan Kaliwungu Kabupaten Kudus)," JKM (Jurnal Kesehat. Masyarakat) Cendekia Utama, vol. 6, no. 2, p. 62, 2019, doi: 10.31596/jkm.v6i2.297.

[37] Y. Theresiana, L. Triyana, and S. Clara, "Determinants of healthy latrines ownership in working area at public health center of suak tapeh in Banyuasin Regency South Sumatra 2019," Proceedings of the 2nd Sriwijaya International Conference of Public Health (SICPH 2019), vol. 25, no. Sicph 2019, 2019, pp. 268-276.

[38] H. Hayana, "Relationship of latrine ownership coverage in Kampung Baru Village, Pekanbaru City (In Indonesia: Hubungan Cakupan Kepemilikan Jamban Di Kelurahan Kampung Baru Kota Pekanbaru)," J. Kesehat. Glob., vol. 3, no. 1, pp. 9-17, 2020. In English: H. Hayana, "Relationship of latrine ownership coverage in Kampung Baru Village, Pekanbaru City," J. Kesehat. Glob., vol. 3, no. 1, pp. 9-17, 2020.

[39] N. Nurlaila, "Factors related to ownership of toilets in the work area of the Rantau Badauh Health Center, Barito Kuala Regency in 2020 (In Indonesia: Faktor-Faktor Yang Berhubungan Dengan Kepemilikan Jamban Di Wilayah Kerja Puskesmas Rantau Badauh Kabupaten Barito Kuala Tahun 2020)," Thesis, Universitas Islam Kalimantan MAB, 2020.

[40] E. Maryanti, S. Ramona, and L. Hernike, "Factors relating to ownership of family healthy toilets in Busung Village, Teupah Tengah District, Simeulue Regency (In Indonesia: Faktor-Faktor Yang Berhubungan Dengan Kepemilikan Jamban Sehat Keluarga Di Desa Busung Kecamatan Teupah Tengah Kabupaten Simeulue)," J. Kesmas Prima Indones., vol. 2, no. 2, pp. 56-65, 2020.

[41] M. Mukhlasin and E. N. Solihudin, "Healthy latrine ownership in the community (In Indonesia: Kepemilikan Jamban Sehat Pada Masyarakat)," Faletehan Heal. J., vol. 7, no. 03, pp. 119-123, 2020.

[42] Ministry of Health Indonesia, "National open defecation free (ODF) Progress Report," Ministry of Health Indonesia, 2021. http://monev.stbm.kemkes.go.id/monev/ (accessed Apr. 03, 2021).

[43] R. Anuradha, R. Dutta, J. D. Raja, D. Lawrence, J. Timsi, and P. Sivaprakasam, "Role of community in Swachh Bharat Mission. Their knowledge, attitude and practices of sanitary latrine usage in rural areas, Tamil Nadu," Indian J. community Med. Off. Publ. Indian Assoc. Prev. Soc. Med., vol. 42, no. 2, p. 107, 2017.

[44] V. K. Lopez, V. J. Berrocal, B. C. Angulo, P. K. Ram, J. Trostle, and J. N. S. Eisenberg, "Determinants of latrine use behavior: the psychosocial proxies of individual-level defecation practices in rural coastal Ecuador," Am. J. Trop. Med. Hyg., vol. 100, no. 3, pp. 733-741, 2019.

[45] N. Kumar and P. Jain, "A Study to Assess the Knowledge of Adults regarding the Importance of Sanitary Latrine in Selected Rural Area at Bhopal,” Indian J. Holist. Nurs. (ISSN 2348-2133), vol. 10, no. 1, pp. 8-15, 2019. 
[46] S. B. Patil, "A descriptive Study to identify the knowledge regarding awareness about Sanitary Latrine among people of Herele village, Kolhapur District, with a view to develop an informational Booklet," Int. J. Nurs. Educ. Res., vol. 7, no. 1, pp. 92-100, 2019 .

[47] P. Routray, W.-P. Schmidt, S. Boisson, T. Clasen, and M. W. Jenkins, "Socio-cultural and behavioural factors constraining latrine adoption in rural coastal Odisha: an exploratory qualitative study," BMC Public Health, vol. 15, no. 1, pp. 1-19, 2015

[48] R. K. Ross et al., "Evaluation of household latrine coverage in Kewot woreda, Ethiopia, 3 years after implementing interventions to control blinding trachoma," Int. Health, vol. 3, no. 4, pp. 251-258, 2011, doi: 10.1016/j.inhe.2011.06.007.

[49] F. Meri and R. R. K. Dewi, "Factors related to ownership of healthy latrine by households in Indonesia (Literature Review), (In Indonesia: Faktor-Faktor Yang Berhubungan Dengan Kepemilikan Jamban Sehat Oleh Rumah Tangga Di Indonesia (Literatur Review))," JUMANTIK J. Mhs. dan Peneliti Kesehat., vol. 7, no. 2, pp. 1-15, 2021.

[50] D. Asnake and M. Adane, "Household latrine utilization and associated factors in semi-urban areas of northeastern Ethiopia," PloS ONE. vol. 15, no. 11, 2020.

[51] Y. Shirai, C. Podhisita, and P. Tipsuk, "Latrine development in Thailand," Sanit. Value Chain, vol. 4, no. 3, pp. 21-36, 2020.

\section{BIOGRAPHIES OF AUTHORS}

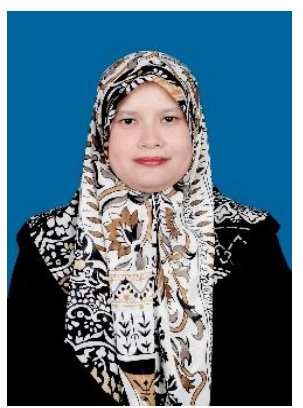

Dyah Suryani (D) SC P is an Assistant Professor at the Faculty of Public Health, Ahmad Dahlan University, Yogyakarta, Indonesia. Previously, Dr. Dyah Suryani received a master's and doctorate degree from Gadjah Mada University, Yogyakarta. For several decades, she has been involved in hygiene and sanitation, focusing on food safety, HACCP, and in general environmental health. She can be contacted at email: dyah.suryani@ikm.uad.ac.id.

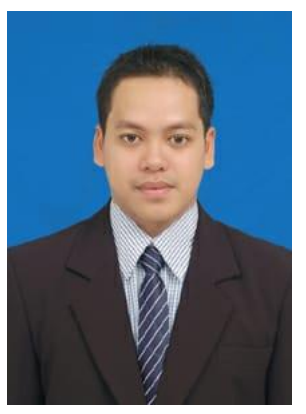

Abil Rudi (D) 8d SC P is a Lecturer at Kapuas Raya College of Health Science, Sintang District, West Kalimantan, Province. He is a nurse. His expertise is teaching research methodology and statistics at Stikes Kapuas Raya Sintang, West Kalimantan until now. He can be contacted at email: abilrudistg@gmail.com.

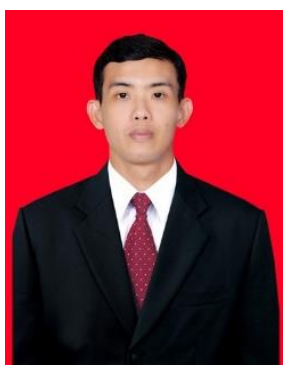

Hairil Akbar (D) SII SC P is a Lecturer at Public Health Program, Graha Medika Institute of Health and Technology, Kotamobagu, Indonesia. He is active in raising environmental health issues in Indonesia in journal publications. To discuss further related to environmental health issues, He can be contacted at email: hairil.akbarepid@gmail.com.

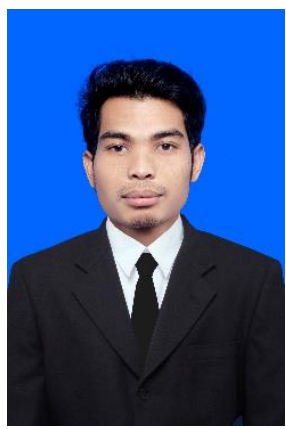

Hizriansyah (D) I8 SC P is a Master of Public Health (MPH) student at Faculty of Medicine, Public Health, and Nursing, Gadjah Mada University, Indonesia. As a student specializing in health information systems, he is always eager to learn about environmental health issues, previously he earned a bachelor's degree in public health at the Faculty of Public Health, Ahmad Dahlan University, Yogyakarta. He can be contacted at email: hizriansyah@mail.ugm.ac.id. 


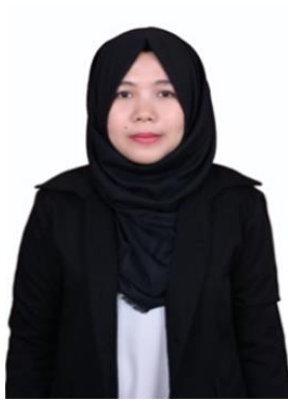

Maretalinia (D) 8d SC P (Candidate) in Demography, Institute for Population and Social Research, Mahidol University, Thailand. She served for two years at the Indonesia-Malaysia border as a member of the Niusantara Sehat II team. Then she received a full funded scholarship from the Faculty of Graduate Studies, Mahidol University, Thailand (Master degree and Ph. D). She's scientific fields are reproductive health, population and social sciences. She can be contacted at email: mareta.linia.21@gmail.com.

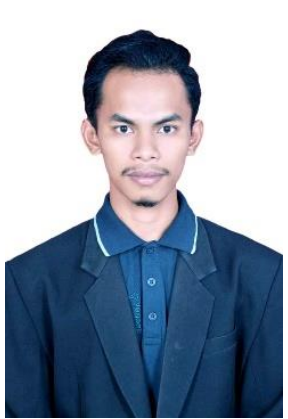

Suyitno (iD SC SC is an Alumni Student at Master of Primary Healthcare Management, ASEAN Institute for Health Development, Mahidol University, Thailand. Active as a research assistant at the Indonesian Ministry of Health's health research and development agency from 2019 to 2021. His scientific fields are environmental health and health development. He can be contacted at email senopalawija@gmail.com.

\section{APPENDIX}

Table 1. Characteristic of reviewed study

\begin{tabular}{|c|c|c|c|c|c|}
\hline No & Author & Location & Sample & Study design: variables & Findings \\
\hline 1. & [27] & $\begin{array}{l}\text { Tapanuli Selatan } \\
\text { District, Nort Sumatera } \\
\text { Province, Indonesia }\end{array}$ & $\begin{array}{c}184 \\
\text { respondents }\end{array}$ & $\begin{array}{l}\text { Crossectional Study: ownership of } \\
\text { latrine and level of knowledge, } \\
\text { attitude, defecation habits, role of } \\
\text { practitioner. }\end{array}$ & $\begin{array}{l}\text { Only } 20.6 \% \text { percent have the } \\
\text { latrine in their household and low } \\
\text { education levels. The significant } \\
\text { predictor was the role of the } \\
\text { health practitioner. }\end{array}$ \\
\hline 2. & [28] & $\begin{array}{l}\text { Leuwikidang village, } \\
\text { kasokandel sub-district, } \\
\text { majalengka district, } \\
\text { West Jawa Province, } \\
\text { Indonesia. }\end{array}$ & $\begin{array}{c}92 \\
\text { household }\end{array}$ & $\begin{array}{l}\text { Crossectional study: ownership } \\
\text { latrine and education level, } \\
\text { occupation, income level, ownership } \\
\text { clean water facilities, land } \\
\text { ownership. }\end{array}$ & $\begin{array}{l}\text { About } 60.9 \% \text { of households did } \\
\text { not have a latrine. } 53.3 \% \text { have no } \\
\text { job, approximately have good } \\
\text { income; } 41.3 \% \text { and } 66.3 \% \text { of } \\
\text { them have no source of water. }\end{array}$ \\
\hline 3. & [29] & $\begin{array}{l}\text { Malikian Village, } \\
\text { Mempawah District, } \\
\text { West Kalimantan } \\
\text { Province }\end{array}$ & $\begin{array}{c}64 \\
\text { household }\end{array}$ & $\begin{array}{l}\text { Crossectional study: ownership } \\
\text { latrine and education levels, income, } \\
\text { knowledge, attitude, role of health } \\
\text { practitioner. }\end{array}$ & $\begin{array}{l}\text { About } 62.5 \% \text { household did not } \\
\text { have the latrine. The all the } \\
\text { independent variable that predictor } \\
\text { with ownership of latrine except } \\
\text { the role of health practitioner. }\end{array}$ \\
\hline 4. & [30] & $\begin{array}{l}\text { Empakan village, } \\
\text { Sintang District, West } \\
\text { Kalimantan Province }\end{array}$ & $\begin{array}{c}62 \\
\text { respondents }\end{array}$ & $\begin{array}{l}\text { Crossectional study: ownership } \\
\text { latrine and educational level, income, } \\
\text { knowledge, attitude, and culture. }\end{array}$ & $\begin{array}{l}55 \% \text { of respondent did not have } \\
\text { latrine in the household. } \\
\text { Education, income, knowledge, } \\
\text { attitude and culture are } \\
\text { significant associated. }\end{array}$ \\
\hline 5. & [31] & $\begin{array}{l}\text { Tambak Lorok village, } \\
\text { Semarang district, } \\
\text { Central of Jawa } \\
\text { Province. }\end{array}$ & $\begin{array}{c}92 \\
\text { respondents }\end{array}$ & $\begin{array}{l}\text { Crossectional study: Ownership } \\
\text { latrine and Education, family } \\
\text { income, knowledge, attitude, source } \\
\text { of clean water, distance from house } \\
\text { to river, family support, and support } \\
\text { from community leaders. }\end{array}$ & $\begin{array}{l}65.2 \% \text { respondents did not have } \\
\text { the latrine. All of independent } \\
\text { variables were predictor of } \\
\text { ownership of latrine except the } \\
\text { source of clean water and support } \\
\text { from community leaders. }\end{array}$ \\
\hline 6. & [32] & $\begin{array}{l}\text { Sukomulyo Village, } \\
\text { Martapura, Palembang } \\
\text { City. }\end{array}$ & $\begin{array}{l}213 \text { head of } \\
\text { households }\end{array}$ & $\begin{array}{l}\text { Crossectional study: Ownership of } \\
\text { latrine and level of education, level } \\
\text { of knowledge, attitude, and family } \\
\text { income. }\end{array}$ & $\begin{array}{l}\text { About } 60.1 \% \text { families not have } \\
\text { latrine in their household. The } \\
\text { predictors are all of independent } \\
\text { variables in this research. }\end{array}$ \\
\hline 7. & [33] & $\begin{array}{l}\text { Polewali village, } \\
\text { Bulukumba District, } \\
\text { South of Sulawesi } \\
\text { Province. }\end{array}$ & $\begin{array}{l}60 \text { head of } \\
\text { households }\end{array}$ & $\begin{array}{l}\text { Crossectional study: Ownership of } \\
\text { latrine and level of education, level } \\
\text { of knowledge, and attitude. }\end{array}$ & $\begin{array}{l}\text { The finding is about } 18.3 \% \text { of } \\
\text { young aged and } 6.7 \% \text { female as a } \\
\text { head of the household. All of } \\
\text { them in the has low education } \\
\text { level and } 50 \% \text { have latrine in } \\
\text { their household. }\end{array}$ \\
\hline 8. & [34] & $\begin{array}{l}\text { Six Eastern District in } \\
\text { Indonesia }\end{array}$ & $\begin{array}{c}1,700 \\
\text { households }\end{array}$ & $\begin{array}{l}\text { A formative study: Toilet ownership } \\
\text { and demographic factors, psychosocial, } \\
\text { normative factors, knowledge, attitude, } \\
\text { and practice (KAP). }\end{array}$ & $\begin{array}{l}\text { The study suggests that social } \\
\text { norms play an important role in } \\
\text { changing sanitation behaviors in } \\
\text { the community. }\end{array}$ \\
\hline
\end{tabular}


9. [35] Ta aniuge village, Parigi Moutong District, Central of Sulawesi Province.

10. [36] Setro Kalangan Village, Kudus District, Central of Jawa Province.

11. [37] Working Area at Public Helath Center (PHC) of Suak Tapeh in Banyuasin Regency South Sumatra Province

12. [38] Kampung baru subdistrict, Pekanbaru City, Riau Province.

13. [39] Working Area at (PHC) of Rantau Baduah in Barito Kuala Regency South Kalimantan

Province

14. Busung Village,

[40] Simeulue District, Aceh Province.

15. [41] Walikukun village, Serang District, Banten Province.
75

respondents

88

respondents:

44 case and

44 control

99

respondents

study: ownership

latrine and clean water availability,

condition of latrine, habit, family

income, and toward healthy latrine

ownership.

$74 \quad$ Crossectional study: ownership

households latrine and age, sex, educational level, job, level of knowledge, family income, source of clean water, and role of health practitioner.

91

households

Crossectional study: ownership

latrine and socio-demographic

factors, level of knowledge, attitude, and family income.

64

households

Crossectional study: ownership of

latrine and level of knowledge, level of education and role of health practitioner.

87

households

Crossectional study: ownership of

latrine and source of clean water, availability of land, family income.
$70.7 \%$ of household is not have the latrine. All of independent variables is predictor of ownership latrine in the household.

Practice and family income have correlation with ownership of latrine in the household.

$57.6 \%$ do not have latrine in the household. The most dominant factor affecting ownership latrine is attitude.

Level of knowledge, family income, and availability of clean water are predictors of ownership latrine in the household.

Factors that influence latrine ownership include knowledge, attitudes, and family income. Only $59.3 \%$ in this study the household which have the latrine. $68.8 \%$ of the household have no latrine and all of independent variable is predictor of ownership of latrine of the household in this study.

$67.8 \%$ household not have latrine. All independent variables were very significantly as a predictor of ownership latrine in the household. 